\title{
Morphological and biological characteristics of selected clones of the purple willow (Salix purpurea L.) 'Gracilis' and evaluation of their productivity in short rotation plantations
}

\author{
Remigijus Noreika \\ Department of Biology, \\ Faculty of Science and Technology, \\ Lithuanian University of Educational Sciences, \\ Studentu St. 39, LT-08106 Vilnius, Lithuania
}

The aim of this research was to study the morphological and biological characteristics of the selected clones of Salix purpurea 'Gracilis' cultivar in short rotation plantations and to evaluate their productivity. By taking these aspects into account, it was attempted to study and evaluate seven selected clones of Salix purpurea 'Gracilis' as well as to summarize the research of their morphological and biological characteristics and their productivity over nine years of growing in short rotation plantations.

After conducting a comparative study of sprout leaves of the selected clones it was determined that the leaves of different clones differ in shape, size and leafstalk length. Some characteristics of biological productivity such as bush height, the number of sprouts grown per bush, their length and diameter, slenderness ratio, and their number per hectare were studied as well.

Key words: Salix purpurea 'Gracilis', clonal selection, short rotation, morphological characteristics

\section{INTRODUCTION}

At the moment in many countries worldwide, including Lithuania, the willow is viewed as a source of renewable energy (Christopherson et al., 1989; Hummel et al., 1989; Ferell et al., 1992; Smaliukas et al., 2008). However, another area where willow and osier wood is used and which has long traditions in Lithuania is the wickerwork business (Mirinauskas, 1992). The development and profitability of this business depends on the constant

*Corresponding author. E-mail: remigijus.noreika@leu.lt supply of high quality and rapidly growing osier and willow switches. Traditionally, the main species that produce switches suitable for wickerwork are considered to be Salix purpurea, S. viminalis, S. triandra and some other species and their interspecies taxa (Stott, 1992; Smaliukas, Noreika, 2005). Of these species, the most widely grown in Lithuania is $S$. purpurea and its interspecies taxa, including the cultivar 'Gracilis', the cultural population of which is quite varied. Individual bushes of $S$. purpurea stand out in terms of the number of sprouts grown per bush and their morphological characteristics. 
The aim of this research was to study the morphological and biological characteristics of the selected clones of Salix purpurea 'Gracilis' cultivar in short rotation plantations and to evaluate their productivity.

\section{MATERIALS AND METHODS}

The selection of Salix purpurea 'Gracilis' clones was carried out in cultured osier plantations of Noreikupis (Šakiai District), Seredžius (Jurbarkas District) and Miroslavas (Alytus District) in 1996.

In April of 1997 the selected splits of S. purpurea 'Gracilis' cultivar clones were planted in the prepared willow and osier field collections. The method of growing willows and osiers for one year and then cutting them each year at the end of vegetation was used to evaluate the morphological and biological characteristics of the bushes and the productivity of the vegetative stock. Also the morphological and biological characteristics and the productivity of sprouts over the nine years of cultivation of the selected clone bushes were studied and evaluated.

Field collections were set up in peaty sandy loam soil. The concentration of macroelements and microelements in the soil $(\mathrm{mg} / \mathrm{kg})$ was as follows: $\mathrm{N}_{-} \mathrm{NO}_{3}$ (15.9), $\mathrm{K}_{2} \mathrm{O}$ (86), $\mathrm{P}_{2} \mathrm{O}_{5}$ (85), $\mathrm{Ca}$ (1377), Mg (250), Fe (440), Zn (1.5), $\mathrm{Mn}$ (40), B (0.6), and $\mathrm{Cu}$ (1.1). Soil pH was 6.2.

Bushes in the field collections were planted in rows. The spaces between rows were $70 \mathrm{~cm}$ and $25 \mathrm{~cm}$ between plants. The planted split length was $25 \mathrm{~cm}$. The field was fertilized with potassium and phosphorus in autumn, whereas nitrogen was used in spring (the dosage of active substances was the following: $\mathrm{N}_{50}, \mathrm{~K}_{80}, \mathrm{P}_{60}(\mathrm{~kg} / \mathrm{ha})$ ).

The morphological characteristics and the productivity of bushes and sprouts were studied based on the research methods of model plants (Klein, Klein, 1974). The obtained results were analysed using statistical methods.

\section{RESULTS AND DISCUSSION}

Growing of one-year-old sprouts of willows and osiers (i. e. growing switches which are used in the wickerwork business after removing their bark) in short rotation plantations is very similar to the growing of cultivated plants. Plant growing duration in plantations for switches is one year; for the production of wickerwork furniture and other products, the duration is two to three years. The main requirements that apply to osiers and their clones (genetically identical vegetative offspring) grown in short rotation plantations are the number of sprouts produced per bush, their length and diameter, slenderness ratio, and pest and disease resistance. By taking these aspects into account, it was attempted to study and evaluate the seven selected clones of Salix purpurea 'Gracilis' as well as to summarize the research of their morphological and biological characteristics and their productivity over the nine years of growing in short rotation plantations.

After conducting a comparative study of sprout leaves of the selected clones it was determined that the leaves of different clones differ in shape, size, and leafstalk length as shown in Fig. 1. The leaves of clones 9709-9712 are distinctly conversely lanceolate, while the leaves of clones 9713-9742 are linear lanceolate, and the leaves of clone 9741 are wide linear lanceolate. The leaves of clone 9741 have short leafstalks, whereas the acuminate apex of leaves is characteristic of clone 9742. Also, different clones have varying serrated lamina.

After summarizing the size data of sprout leaves during the 7th-9th years of growing (see Fig. 2), it was determined that the studied clones can be grouped into three groups based on the length of their leaves: those growing the shortest leaves (5.6-6.2 cm (clones 9709 and 9710)), those growing medium length leaves (5.4-6.5 cm (clones 9711-9713)) and those growing the longest leaves $(7.2-8.6 \mathrm{~cm}$ (clones 9741-9742)). In the 7th year of growing all three clone bushes grew the widest leaves and during the 7th-9th years of growing the leaves of bushes were marginally narrower. In terms of leaf width, the most distinct were the leaves of clones 9741 and 9742 . It was noticed that leaf size is affected more by the conditions of growing rather than by the age of the bush. 


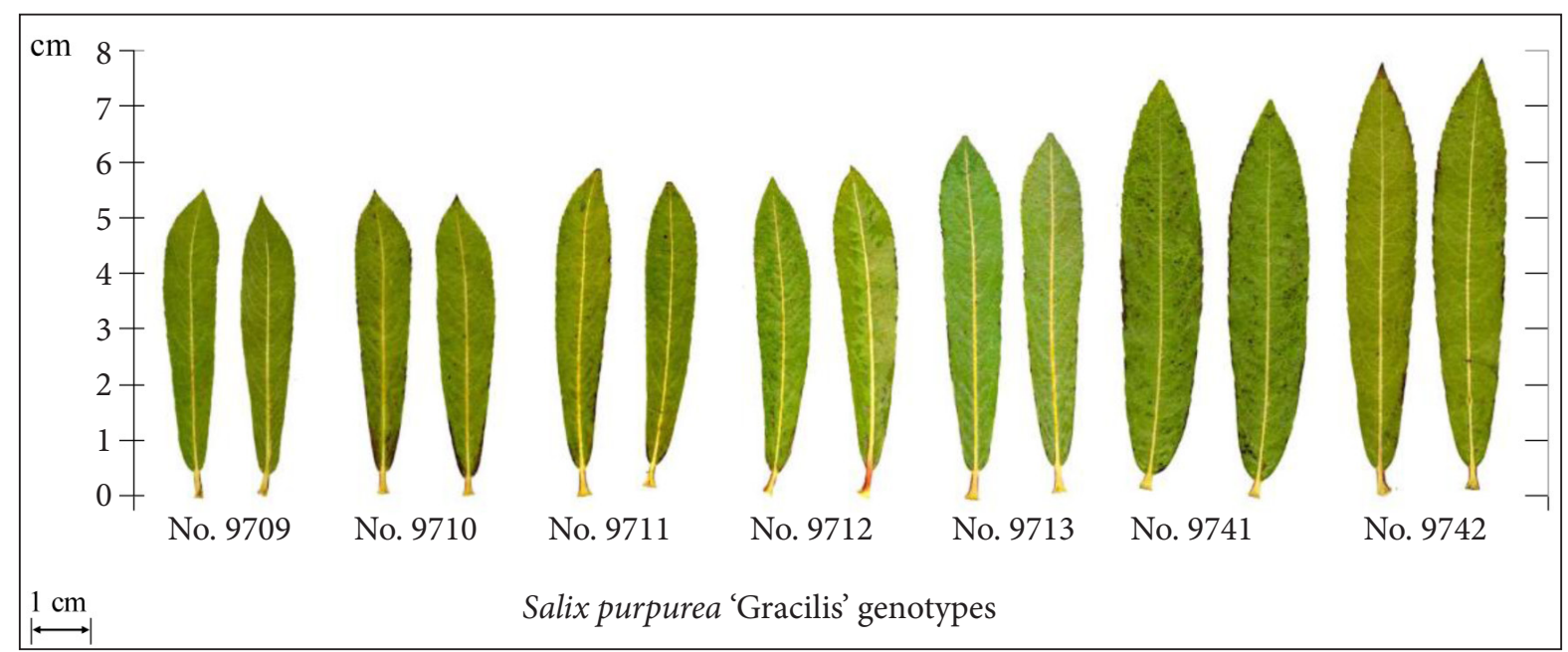

Fig. 1. Leaves characteristic of the selected Salix purpurea 'Gracilis' clone sprouts

After summarizing the intensity of bush growth during the 1 st -4 th and 7 th-9th years of growing, it was determined that the clones differ in growth character (see Fig. 3). During the 1st year of growing the height of bushes at the end of vegetation varied between $75 \mathrm{~cm}$ (clone 9710) and $99 \mathrm{~cm}$ (clones 9711 and 9742). The growth rate during the 1 st and later years depends on many factors: the genetic characteristics of the clone, the soil, rhizogenesis, the time of planting and agrotechnical treatment. Taking into account the conditions in Lithuania, it is crucial to finish planting the sticks of clones until the 20th of April.

Cutting time and stump height during the 2nd and later years of growing have great impact on the renewal of sprouts. The most advisable time for cutting is autumn (during the months of October and November); spring cutting (especially if it is belated) decreases the intensity of bush growth and the productivity of grown material. The sprouts of all studied clones grow very rapidly and become suitable for use in production during the 2 nd

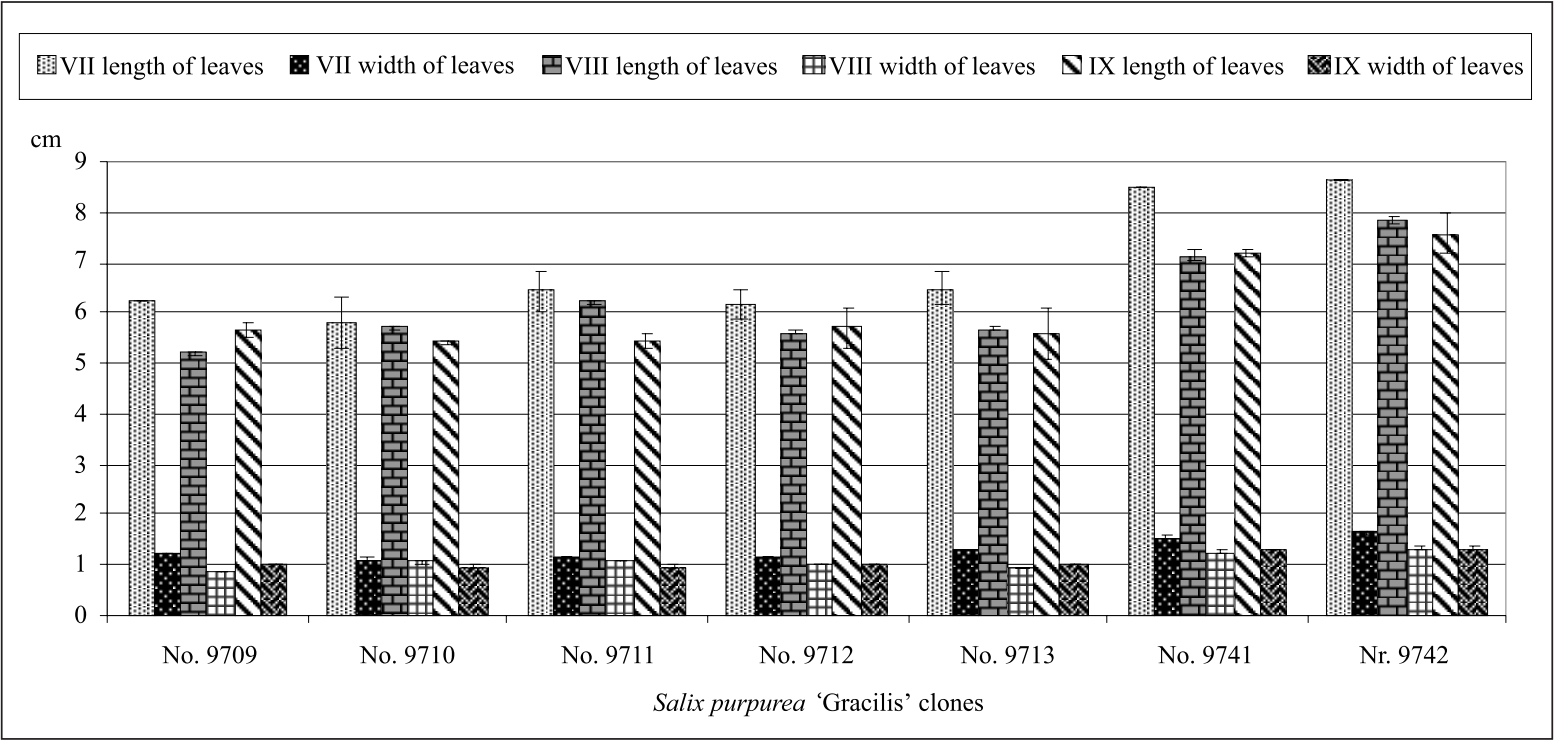

Fig. 2. Leaf length and width evaluation of Salix purpurea 'Gracilis' clone sprouts during 7th-9th years of growing 


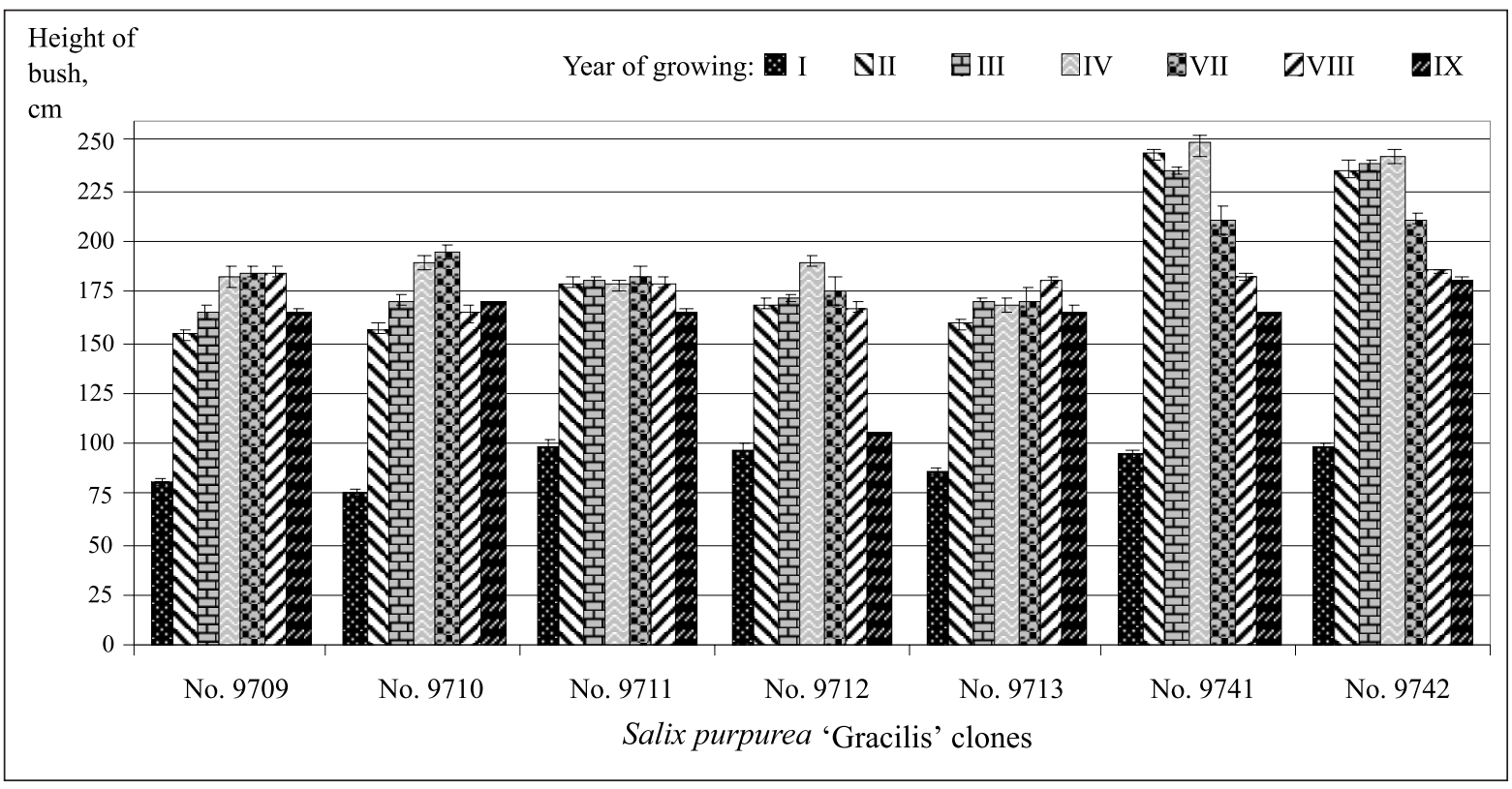

Fig. 3. The height of one-year-old old Salix purpurea 'Gracilis' clone sprouts during the 1st-4th and 7th-9th years of growing

year of growing when the root system becomes stronger. The highest bushes during the 2 nd year were grown by clones $9741(243 \mathrm{~cm})$ and 9742 $(236 \mathrm{~cm})$. The height of other clone bushes varied between $154 \mathrm{~cm}$ (clone 9709) and $179 \mathrm{~cm}$ (clone 9711).

During the 3rd year of growing a slight increase in bush height was observed, except for clone 9741 in which case the average bush height was $8 \mathrm{~cm}$ lower.

During the 4 th year of growing some selected clone bushes reached their maximum height: clone $9712(190 \mathrm{~cm})$, clone $9742(242 \mathrm{~cm})$, and clone $9741(248 \mathrm{~cm})$.

During the 7 th, 8 th, and especially the 9th year of growing there was an observable decrease in bush height of clones 9712 and 9742. For this reason after eight years of yearly cutting of the sprouts, it is advisable to make a pause in bush cutting in order to allow their root system to strengthen.

The number of sprouts is a biological characteristic of clones on which depend the output of switches and the productivity of the plantation. As can be seen in Fig. 4, clones vary in the number of sprouts. It was observed that common to all clones is the variation of the number of sprouts per bush depending on the year of growing. During the 1st year of growing the number of sprouts varied between 2.5 (clone 9709) and 4.4 (clone 9742). During the 2 nd year of growing the number of sprouts increased 3.3-7.3 times. During the $3 \mathrm{rd}$ and 4 th years of growing the majority of clone bushes grew a maximum number of sprouts (clone 9710 (47.8 sprouts), clone 9711 (41.7 sprouts), clone 9709 (30.5 sprouts), and clone 9741 (26.3 sprouts)). The data shows that the clones of Salix purpurea 'Gracilis' significantly exceed other cultivars grown in the $S$. purpurea culture in terms of the number of sprouts grown per bush, e. g. S. purpurea 'Rubra' (19.7 sprouts), S. purpurea f. purpurea (18.3 sprouts), and S. purpurea f. busulukensis (16.8 sprouts) (Smaliukas, Noreika 2002). During the 7 th-9th years of growing the number of sprouts per bush of some clones decreased while in others it increased.

Long, straight, flexible and branchless switches are valued most in production. There is also a demand for switches which are shorter and have fixed slenderness (i. e. the thickness across the length of the switch changes slowly), and are used in production of some 


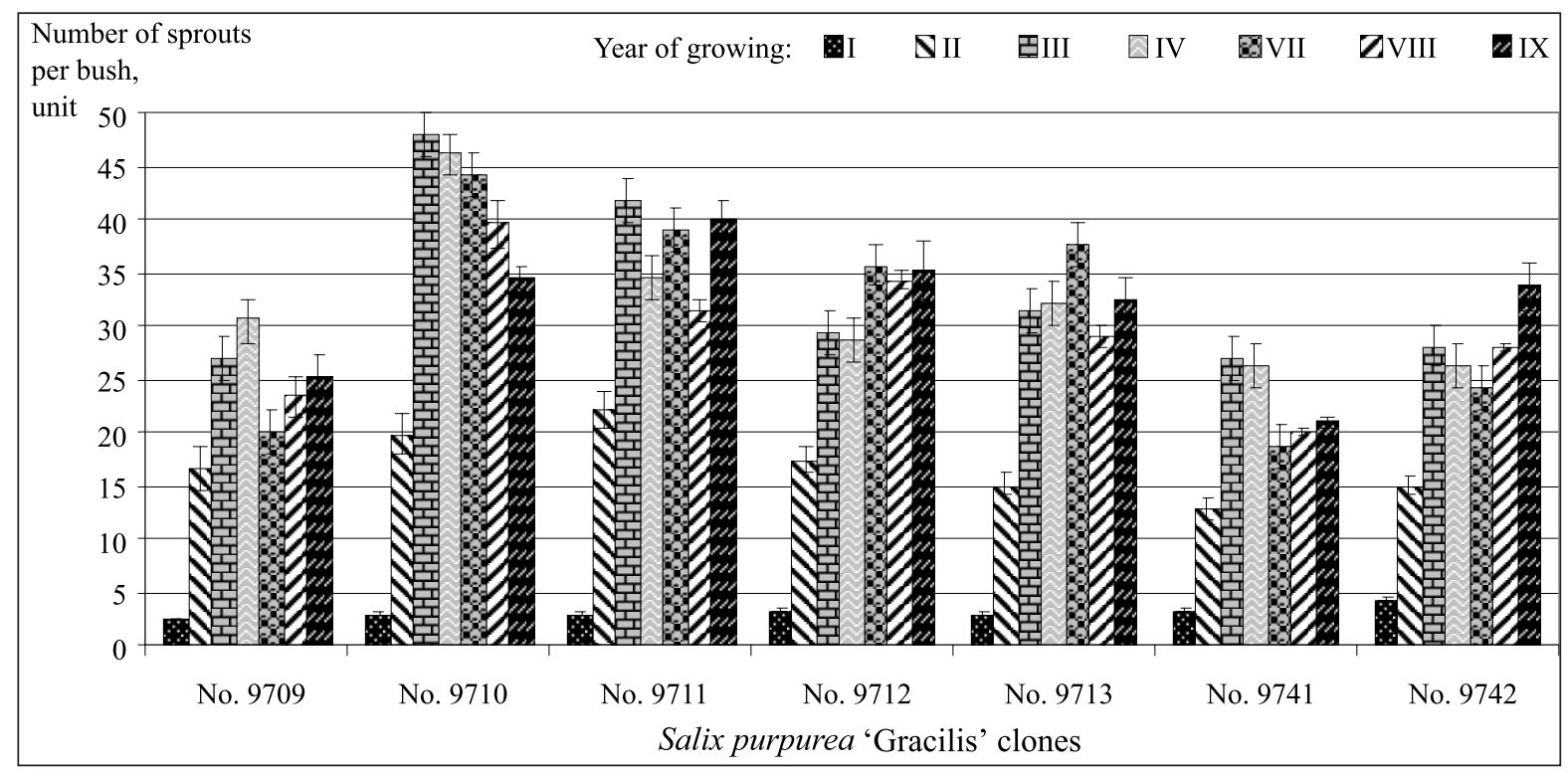

Fig. 4. The number of one-year-old Salix purpurea 'Gracilis' clone sprouts during the 1st-4th and 7th-9th years of growing

products. Such sprouts (switches) are produced only by $S$. purpurea 'Gracilis' clones (their average length is determined after cutting and analysing all sprouts which were produced by the bush). As can be seen in Fig. 5, the average length of four out of five sprouts of clones 9710-9713 which were studied and evaluated was quite stable (during the 2 nd -8 th years of growing it varied between $115 \mathrm{~cm}$ and $139 \mathrm{~cm}$ ). The longest sprouts (switches) were produced by clone $9741(156 \mathrm{~cm})$ and clone $9742(153 \mathrm{~cm})$. During the 9th year of growing, the average switch length of all the studied clones decreased.

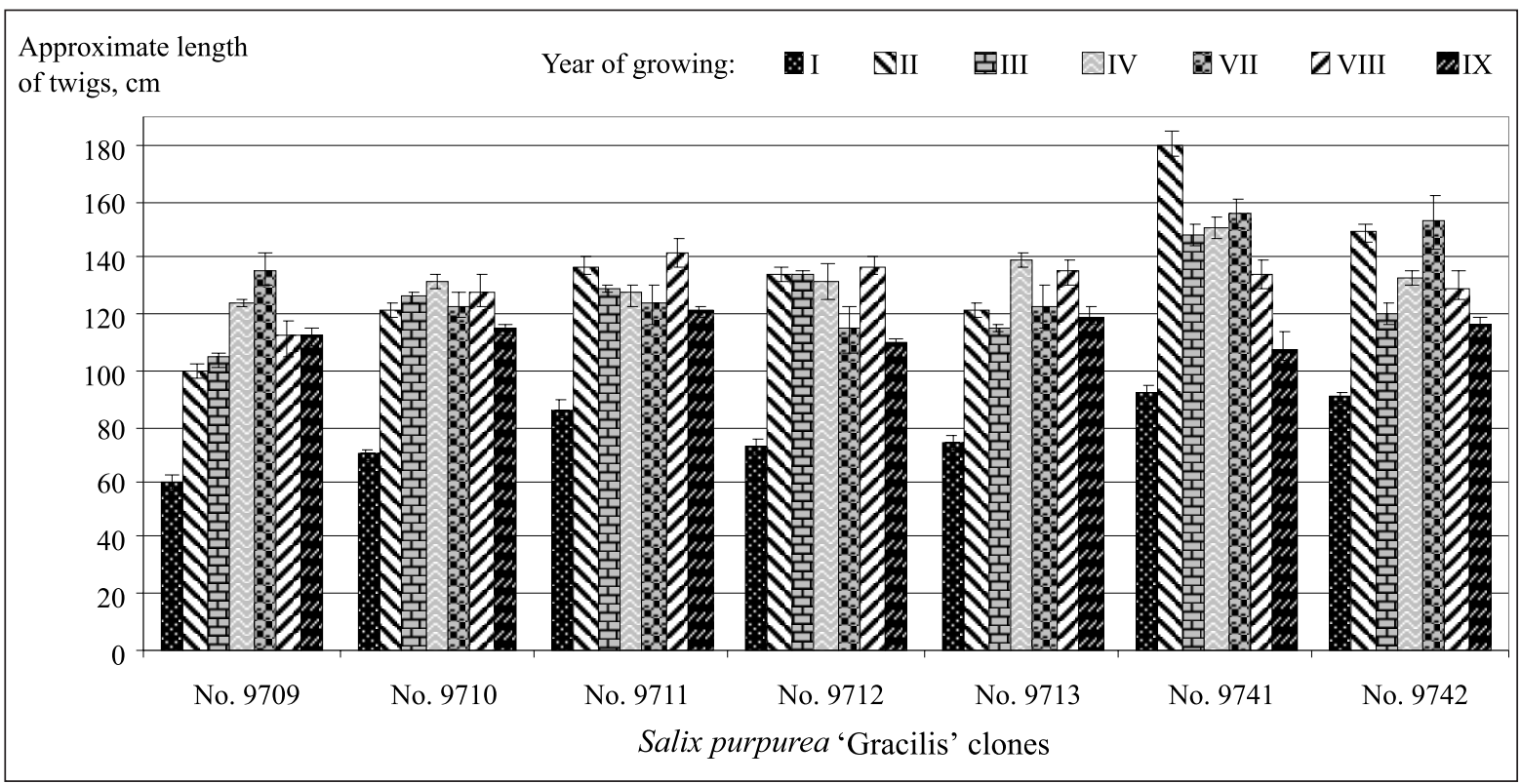

Fig. 5. The average length $(\mathrm{cm})$ of one-year-old Salix purpurea 'Gracilis' clone sprouts (switches) during the 1st-4th and 7th-9th years of growing 
One of the most typical and distinctive morphological qualities of S. purpurea 'Gracilis' clones is their ability to produce sprouts (switches) which are small in diameter (thin). After measuring the diameter of sprouts at the butt end and at the height of $100 \mathrm{~cm}$, the slenderness ratio of sprouts was determined. The highest quality switches are those of fixed slenderness. As can be seen in Fig. 6, the diameter and the slenderness ratio of different sprouts differ. The thinnest sprouts (switches) were produced by clone 9709 (4 $\mathrm{mm}$ at the butt end), whereas the thickest ones were produced by clone 9741 (7-6 mm) and 9742 (6-5 mm). It was determined that the slenderness ratio of switches of the studied clones during different years of growth varied between 1 and $2 \mathrm{~mm}$.

One of the primary objectives of the clonal selection of willows and osiers that are grown for switches are the productivity of selected clones and the quality of the material produced. As can be seen in Fig. 7, during their 1 st year of growing the studied clones produced between 171,000 and 250,800 switches per hectare. During the 2nd year of growing the output of sprouts (switches) increased significantly and varied from clone to clone (from 735,800 (clone 9741) to $1,128,500$ (clone 9710) units per hectare). The majority of the clones studied reached the maximum output of sprouts (switches) during the $3 \mathrm{rd}$ or 4 th years of growing. In terms of the number of sprouts (switches) produced, the most significant clones were 9710 (which produced 2,672,400 sprouts per hectare during the 3rd year of growing) and 9711 (which produced 2,376,900 sprouts per hectare during the 3 rd year of growing). Closest to clones 9710 and 9711 in terms of the number of sprouts (switches) produced were clones 9712, 9713, and 9742 which produced 1,670,100, $1,784,100$ and $1,601,700$ sprouts per hectare, respectively. For comparison, S. purpurea f. purpurea grown in the same conditions produced $1,043,100$ sprouts per hectare during the 3 rd year of growth and S. purpurea f. rubra produced 1,122,900 sprouts per hectare (Smaliukas, Noreika, 2002).

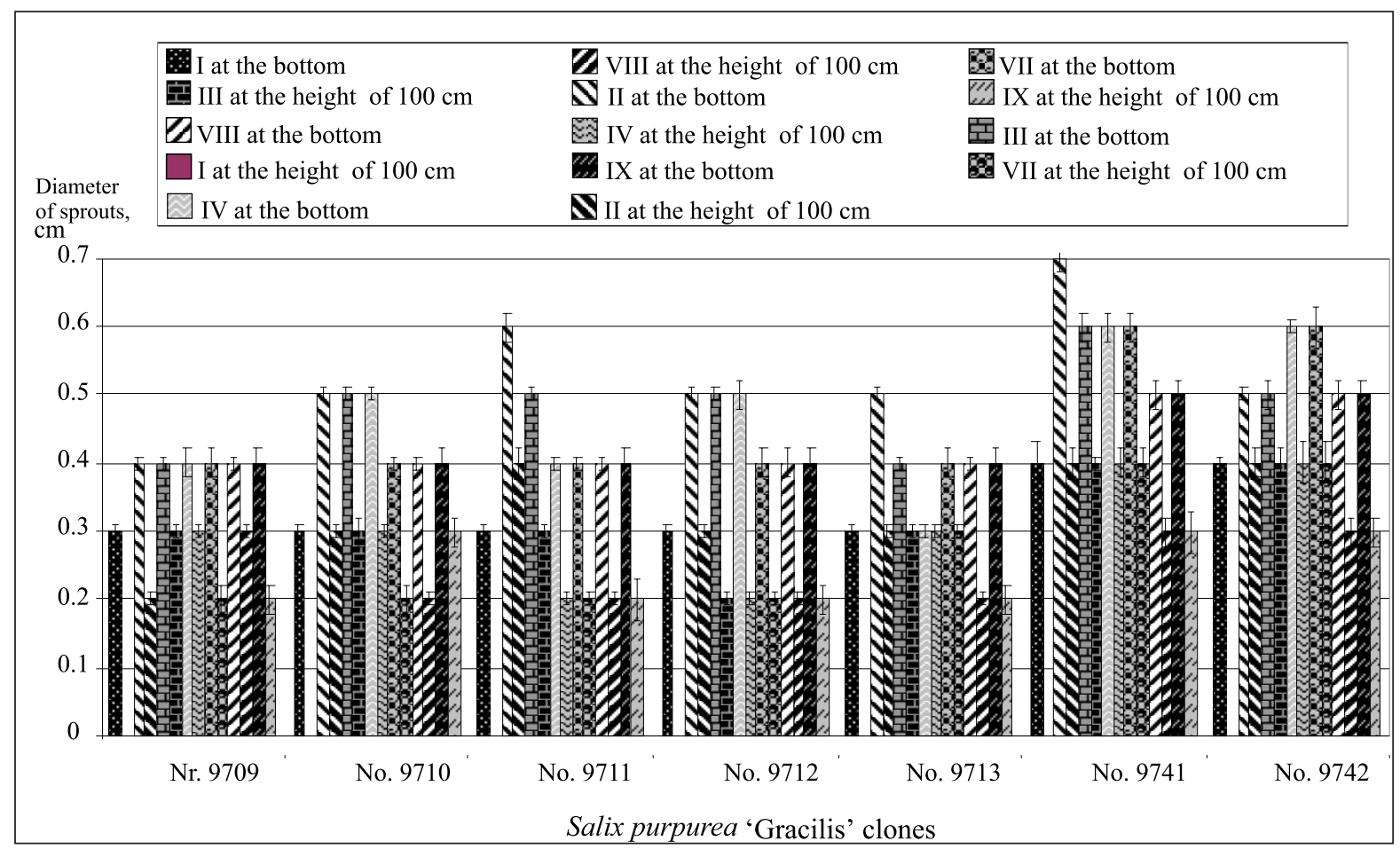

Fig. 6. The diameter of one-year-old Salix purpurea 'Gracilis' clone sprouts at the butt end during the 1st4 th and 7 th-9th years of growing 


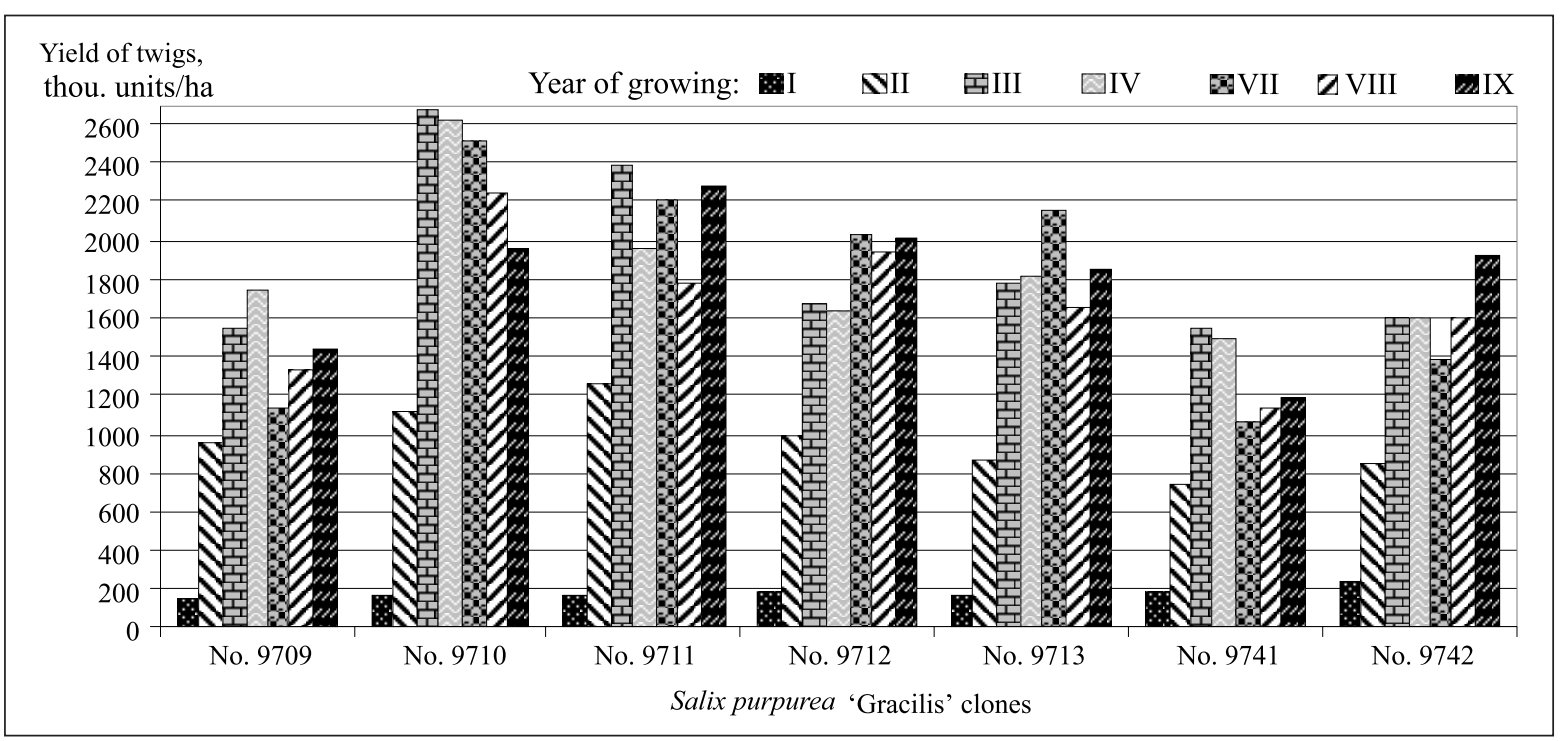

Fig. 7. The output (thousand specimens per hectare) of one-year-old Salix purpurea 'Gracilis' clone sprouts (switches) during the 1st-4th and 7th-9th years of growing

\section{ACKNOWLEDGEMENTS}

The authors are thankful to Associate Professor Dr. Dalius Dapkus and Mantas Noreika for language editing.

Received 29 October 2015

Accepted 12 November 2015

\section{References}

1. Christopherson N, Barkley B, Leolin S, Mitchell CP. Production Technology for Short Rotation Forestry - IEA information report SUAS. 1989; 88-1: 87.

2. Ferell J. Country report for short rotation forestry - USA [handbook]. Uppsala, Sweden: Swedish University of Agricultural Sciences; 1992.

3. Hummel FC, Palz W, Grassi G. Biomass Forestry in Europe: a strategy for the Future. London-New-York; 1989.
4. Klein PM, Klein DT. Metody issledovanija rastenij. Moskva; 1974.

5. Mirinauskas K. Viskas iš vytelių. Vilnius; 1992.

6. Smaliukas D, Noreika R. Genetic resources, clonal selection and estimation of productivity of valuable clones of purple willow (Salix purpurea L.). Biologija (Vilnius). 2002; 1: 75-7.

7. Smaliukas D, Noreika R. Morphobiological characteristics and evaluation of productivity of Salix L. clones selected for short-rotation coppice. Biologija. 2005; 3: 36-40.

8. Smaliukas D, Noreika R, Puida E. Evaluation of morphobiological, biomass and energetic characteristics of Salix viminalis and S. dasyclados Wimm. genotypes in short rotation plantations. Biologija. 2008; 2: 97-100.

9. Stott KG. Willows in the service of man. Proceedings of the Royal Society of Edinburgh 98 B. 1992. p. 169-82.

10. Zaicev GN. Matematičeskaja statistika v eksperimentalnoj botanike. Moskva; 1954. 


\section{Remigijus Noreika}

\section{PURPURINIO KARKLO}

(Salix purpurea L.) 'GRACILIS'

SELEKCIONUOTŲ KLONŲ MORFOLOGINĖS IR BIOLOGINĖS SAVYBĖS IR JŲ PRODUKTYVUMO İVERTINIMAS TRUMPOS APYVARTOS ŽELDINIUOSE

\section{Santrauka}

Tyrimų tikslas - apibendrinti auginamų ir tiriamų trumpos apyvartos želdiniuose selekcionuotų Salix purpurea 'Gracilis' klonų morfologines ir biologines savybes ir įvertinti produktyvumą.

Šiais aspektais ištirti ir įvertinti septyni selekcionuoti Salix purpurea 'Gracilis' klonai, apibendrinti jų morfologinių ir biologinių savybių bei produktyvumo tyrimai per devynerius auginimo trumpos apyvartos želdiniuose metus.

Atlikus selekcionuotų klonų atžalinių ūglių lapų palyginamuosius tyrimus nustatyta, kad atskirų klonų lapai skiriasi pagal formą, lapo lakšto dydi ir lapkočio ilgị. Ryškiai atvirkščiai lancetiški yra 97099712, linijiškai lancetiški - 9713-9742 klonų lapai, o 9741 klono lapai yra plačiai linijiškai lancetiški. 9741 klono lapai išsiskiria trumpu lapkočiu, o 9742 klono - ilgai smailejjančia viršūne. Taip pat skirtingų klonų lapams būdingas ịvairuojantis lapo lakšto pjūkliškumas.

Tirtus klonus pagal lapų ilgi galima sugrupuoti i 3 grupes: išauginančius trumpiausius lapus - 5,6$6,2 \mathrm{~cm}$ (kl. 9709 ir 9710), vidutinio ilgio - 5,4-6,5 cm (kl. 9711-9713) ir ilgiausius lapus - 7,2-8,6 cm (kl. 9741-9742). Septintais auginimo metais visų trijų klonų krūmai išaugino plačiausius lapus, o 7-9 metų krūmų lapai buvo truputị siauresni. Pagal lapų plotị ryškiausiai išsiskyrè 9741 ir 9742 klonų krūmai.

Ketvirtais auginimo metais kai kurie selekcionuoti klonų krūmai pasiekè maksimalų aukštị - $9712 \mathrm{kl}$. $(190 \mathrm{~cm}), 9742 \mathrm{kl}$. $(242 \mathrm{~cm}), 9741 \mathrm{kl}$. $(248 \mathrm{~cm})$. Septintais ir aštuntais, o ypač devintais auginimo metais pastebimas ženklus 9712, 9741 ir 9742 klonų krūmų aukščio žemejjimas. Taigi po aštuonių kasmetinių atžalinių ūglių kirtimų devintais auginimo metais tikslinga padaryti pertrauką, kad sustiprètų augalų šaknų sistema.

Atžalinių ūglių skaičius krūme yra klonų biologinè savybe், nuo kurios priklauso vytelių išeiga ir plantacijos produktyvumas. Pastebimi kai kurie bendri visiems klonams dèsningumai - tai atžalinių ūglių skaičiaus krūme kaita priklausomai nuo auginimo metų. Pirmaisiais auginimo metais atžalinių ūglių skaičius krūme varijuoja nuo 2,5 (9709 kl.) iki 4,4 (9742 kl.); antraisiais jis padideja 3,3-7,3 karto. Trečiaisiais ir ketvirtaisiais auginimo metais daugelio klonų krūmai išaugino maksimalų jų skaičių: (9710 kl. - 47,8 vnt., 9711 kl. - 41,7 vnt., 9709 kl. - 30,5 vnt., 9741 kl. - 26,3 vnt.). Salix purpurea 'Gracilis' klonai pagal išauginamų atžalinių ūglių skaičių krūme gerokai pralenkia kitus $S$. purpurea kultūroje auginamus kultivarus, pavyzdžiui, S. purpurea 'Rubra' - 19,7, S. purpurea f. purpurea - 18,3, S. purpurea f. busulukensis - 16,8.

Vienas iš svarbiausių tikslų, vykdant vytelèms auginamų gluosnių ir karklų kloninę atranką, yra atrenkamų klonų produktyvumas bei augalinès žaliavos kokybè. Pirmaisiais auginimo metais tirtieji S. purpurea 'Gracilis' klonai išaugino nuo 171 iki 250,8 tūkst. vytelių hektare; antraisiais jų išeiga labai padideja ir skirtingų klonų ji varijuoja nuo 735,8 (9741) kl. iki 1 128,5 tūkst. vnt./ha (9710 kl.). Maksimali atžalinių ūglių išeiga pasiekiama trečiais ir ketvirtais auginimo metais. Pagal išauginamų atžalinių ūglių kiekí išsiskyrè 9710 kl., kuris trečiais auginimo metais išaugino 2 672,4 tūkst. vnt./ha, ir 9711 kl., išauginęs 2376,9 tūkst.vnt./ha. Arčiausiai prie minètų klonų pagal išauginamų atžalinių ūglių kieki yra 9712, 9713 ir 9742 klonai, išauginantys atitinkamai 1 670,1, 1 784,1 ir 1 601,7 tūkst. vnt./ha.

Raktažodžiai: Salix purpurea 'Gracilis', kloninè atranka, trumpa apyvarta, morfologinès savybès 